polymorphism and floral evolution. It would be interesting if she could connect up divergence of carpel form with possible phylogenetic lines and developmental tendencies. Does carpel poly. morphism help in interpreting 'convergence', 'parallelism', 'reticulation' and other supposed modifications of what is often considered the ideal type of phylogenetic tree? Does the theory support the view of a monophyletic origin of the Angio- sperms? Does it give new or detailed suggestions as to the nature of 'primitive' carpels? Again, it is probable that in the course of her work Miss Saunders found cause to criticize not only the morphology but also the taxonomy of the taxonomist. $\mathrm{He}$ would welcome her criticisms. There really seems to be a need for a third volume of floral morphology.

W. B. TURRILL.

\title{
INTRODUCING HUMAN ANATOMY
}

\section{The Tissues of the Body}

An Introduction to the Study of Anatomy. By Prof. W. E. Le Gros Clark. Pp. xi +372. (Oxford : Clarendon Press; London: Oxford University Press, 1939.) 15s. net.

$\mathrm{O}^{\mathrm{r}}$

5 late years there has been a rather depressing spate of books that purport to be introductions to the study of anatomy. For the most part these works tend to recapitulate the type of book that was formerly addressed to nurses or students of massage but which is now dished up for the benefit of the medical student. As such they are symptomatic of what in the United States has been termed "the eclipse of Anatomy" and are the outcome of the present tendency to abbreviate the medical student's course in the study of human anatomy. They can only be classed as the products of expediency in a period during which the teaching of anatomy to medical students is definitely undergoing eclipse. If the student is to have his study of anatomy curtailed in an overcrowded curriculum it is but natural that the text-books read by a former generation may prove to be beyond his capacity and his needs.

It is merely a question of relative values. There are those who still fancy that the time devoted to anatomy by the student of some forty years ago was not altogether wasted in the education of a practitioner of medicine.

There are those who think that some three hundred hours are sufficient for learning as much of the intricate structure of the human body as is necessary for one who is afterwards to treat the derangements of this complicated structure. Maybe there were those of an older generation who attached too much importance to the minutiæ of structure and a swing back of the pendulum is but natural. In any event, we have to realize that the present tendency is to reduce the time deroted to the study of anatomy and so to render, for the medical student, the older masterpieces of descriptive anatomy redundant in his library. It is this state of affairs that has produced a host of minor books to meet the lessened need of knowledge demanded from the medical student: and these books are mostly the products of authors to whom the production of a more complete and authoritative work would prove a matter of some embarrassment.

It is therefore an occasion of some satisfaction to meet with a book, written designedly as an introduction to the study of human anatomy, that does not presuppose a lowering of the standard of the student's knowledge and one that is written without an eye to minimum requirements in the medical curriculum and in the examination room. Moreover this book is not the product of one to whom the production of a mere introductory handbook could be pictured as the maximum scientific enterprise. Prof. Le Gros Clark has, in this volume, adopted an almost Hunterian outlook, and in reading his book one is tempted to think that it is only a matter of time before another British anatomist pays open homage to an older tradition in British anatomy and so helps in a renaissance-long overdue - that would end the period of "the eclipse of Anatomy".

The "Tissues of the Body" is not a work on histology, for Le Gros Clark, like Bichat, treats of tissues as the basis of animal organization : moreover he treats of them, so far as present knowledge permits, as living and functional elements. It may be permitted for a reviewer to regard this book as one of the most welcome contributions that has been made to the science of anatomy for many years and to express the hope that it will replace, on the shelves of the medical student's library, several minor works that at present appeal to him under the guise of being introductions to this subject.

F. Wood JoNes. 